\title{
Pushing the Boundaries of Lawful Assisted Dying in the Netherlands? Existential Suffering and Lay Assistance
}

\author{
Suzanne Ost ${ }^{\mathrm{a}, *}$ and Alexandra Mullock ${ }^{\mathrm{b}, *}$ \\ ${ }^{a}$ Law School, Bowland North Lancaster University, UK \\ s.ost@lancaster.ac.uk \\ b Law School, University of Manchester, UK \\ allexandra.mullock@postgrad.manchester.ac.uk
}

\begin{abstract}
Two matters that have a significant presence in the contemporary Dutch assisted dying debate, are the nature of the suffering required for an assisted death to be lawful, and the issue of who can lawfully assist. This article explores whether the lawful medical assisted dying model is too restrictive in failing to recognise existential suffering, considering selected case studies involving such suffering and lay assisted death. It addresses the question whether the Netherlands would take a trip down a slippery slope if the lawful model of assisted death were extended to cases where individuals are 'tired of life'.
\end{abstract}

\section{Keywords}

assisted dying; the Netherlands; existential suffering; suffering from life; lay assistance

\section{Introduction}

This article focuses on two matters that have a significant presence in the contemporary debate surrounding assisted dying in the Netherlands - the nature of the suffering required in order for an assisted death to be lawful and the issue of who can lawfully assist. Moreover, these issues have a wider international relevance since they could pose challenges for any jurisdiction that chooses to legalise physician assisted death (PAD). ${ }^{1}$ Both test the boundaries of what does (and should) count as lawful assisted dying and both challenge the most common, medicalised presentation of assisted dying. ${ }^{2}$ They are thus of especial pertinence in the

*) This article is an output of the AHRC-funded project, The Impact of the Criminal Process on Health Care Ethics and Practice, see further online at: www.law.manchester.ac.uk/research/hccriminalprocess/ index.html. The authors wish to thank John Griffiths, Heleen Weyers, Ton Vink, Petra de Jong and Boudewijn Chabot for their assistance while we gathered research for this article in the Netherlands. We are also grateful to Marleen Eijkholt for her translation of Dutch materials and research assistance, and to John Griffiths and Heleen Weyers for their helpful comments on an earlier version of this article.

1) We are applying this term to both euthanasia and assisted suicide carried out by a physician, since both are permitted under the lawful medical model of assisted dying in the Netherlands.

2) S.A.M. McLean, Assisted Dying: Reflections on the Need for Law Reform (Abingdon: Routledge, 2007) 
Netherlands because of the country's inherently medical model of lawful assisted dying. Provided a competent individual is suffering unbearably, this suffering stems from a medical condition and there is no prospect for improvement in her condition, ${ }^{3}$ she can turn to her physician for assistance to die. This means that a lawful assisted death is not available for an individual whose suffering is existential in origin, rather than medical, even if her suffering is just as unbearable to her as it is to another whose suffering does stem from a medical condition. Thus, if a patient requests that her doctor provide her with an assisted death because the side-effects of old age have caused her to be 'tired of life', the doctor will in all likelihood conclude that the criteria for a lawful assisted death have not been met, absent any suffering that stems from a medical condition.

The question of whether the lawful medical model is too restrictive in failing to recognise existential suffering has recently been brought to the fore by the 'Completed Life' campaign launched in 2010 by the NVVE, ${ }^{4}$ the largest right-todie organisation in the Netherlands. The NVVE's objective is to 'contribute to an open debate that will lead to the realization of a solution... for people who consider their life completed, and, therefore, prefer death over life. ${ }^{5}$ The launch of the campaign coincided with a Citizen's Initiative founded by a citizens' action group, Uit Vrije Wil (Out of Free Will). ${ }^{6}$ The 'Accomplished Life' initiative, which demands that individuals over 70 who are tired of life should have the right to an assisted death, was ultimately supported by 116,871 signatures. $^{7}$

Turning to the second issue that forms the focus of our analysis, the medical model of assisted dying in place in the Netherlands means that an individual can only turn to a physician for lawful assistance. A common sense assumption might be that lay assisted death (LAD) ${ }^{8}$ will thus not occur, or occur infrequently unless the lawful medical model is not adequately providing for those who desire an AD. The situation could then be contrasted with that in jurisdictions like the UK,

p. 181; S. Ost, "The De-medicalisation of Assisted Dying: Is a Less Medicalised Model the Way Forward?", Med L Rev 18(4) (2010), 497-540.

3) And her case meets the rest of the due care criteria. See Section 2.

4) The Nederlandse Vereniging voor een Vrijwillig Levenseinde (Right to Die — Netherlands), founded in 1973. See online at: www.nvve.nl/.

5) NVVE, Completed Life: What are we talking about? Questions and answers, (Amsterdam: NVVE, 2010),

6. Retrieved 3 October 2010 at: www.nvve.nl/assets/nvve-english/publications/CompletedLife.pdf.

6) The democratic process in the Netherlands enables Dutch citizens to put a proposal forward that will be put on the agenda for consideration by the Second Chamber of the Dutch parliament provided the initiators gather 40,000 signatures in support of the proposal.

7) See online at: www.uitvrijewil.nu/. See J. Vonkerman, "'Of free Will' causes storm of reactions and discussion", Relevant 36(2) (2010); L. Enthoven, "'Completed Life' on the political agenda", Relevant 36(1) (2010). English summaries of both retrieved 3 October at: www.nvve.nl/nvve-english/pagina. asp?pagkey=143029\&metkey=449; " "Right to die" for elderly back at centre of Dutch debate', Radio Netherlands Worldwide, 9 February 2010. Retrieved 3 October 2010 at: www.rnw.nl/english/article/ right-die-elderly-back-centre-dutch-debate.

8) In this article, we utilise the term LAD for any case where it is not a medical professional who assists. Thus, if a member of a right-to-die organisation is the assistor, this would be an instance of LAD. 
where PAD is unlawful — the lack of any lawful model of assisted dying explains why assisted dying cases involving relatives (RAD) ${ }^{9}$ are occurring in the UK the only option for a person who wishes to avail themselves of an assisted death is to find someone prepared to break the law to provide assistance and such a person is most likely to be a loved one. ${ }^{10}$ In fact, as the case studies in this article reveal, the Netherlands is witnessing the occurrence of LAD and RAD. That these phenomena do take place in the Netherlands raises a number of interesting questions and poses challenges for the legislature and prosecutorial authorities.

In this article, we have selected three cases studies involving existential suffering and/or LAD where the assistor was a physician, a relative or, in the final example, a member of a right-to-die organisation. Through our analysis, we seek to address the following questions: Can and should the lawful medical model of assisted dying encompass existential suffering? Does the occurrence of LAD suggest that the lawful medical model of assisted death is too restrictive? Are assistors in RAD cases to be perceived as criminals, or victims of circumstance, compelled to act because of the desire to relieve their loved one's suffering when no lawful avenue of assistance is available? Might public support for the actions of relative assistors and a sympathetic legal response empower them, enabling them to escape the strict application of the criminal law and process? If the Dutch criminal law and process adopts a more sympathetic response towards $\mathrm{RAD}$, does this response become less benevolent when the assistor is a member of a right-to-die organisation? What factors tend to make it more likely that cases of LAD will be prosecuted and a sentence imposed on conviction? And finally, if the lawful model of assisted death were to be extended to apply in the case of existential suffering, would this mean that the Netherlands had taken a trip down a slippery slope in respect of the law surrounding assisted death? Before considering these questions, however, we begin by outlining the legal position on assisted dying in the Netherlands.

\section{The Current Legal Position on Assisted Dying in the Netherlands}

Articles 293 and 294 of the Dutch Penal Code prohibit euthanasia (when a person 'terminates another person's life at that person's express and earnest request') and assisted suicide (when a person 'assists another to commit suicide or provides him with the means to do so'). The maximum penalty is twelve years imprisonment for euthanasia and three years for assisted suicide. The legal basis for

\footnotetext{
9) In this article, references to RAD encompass cases where it is a relative who is the assistor.

10) Consider, for instance, the Gilderdale case - 'Mother cleared of ME daughter's attempted murder', BBC News, 25 January 2010. Retrieved 3 October 2010 at: http://news.bbc.co.uk/1/hi/england/sussex/8479211.stm and the other following examples: 'Assisted suicide man walks free', BBC News report. Retrieved 3 October 2010 at: http://news.bbc.co.uk/1/hi/england/southern_counties/6065836.stm; 'Rugby star Dan James in "assisted suicide" after training injury', The Times, 18 October 2008.
} 
allowing PAD exists under the Termination of Life on Request and Assisted Suicide (Review Procedures) Act of 2002 (hereafter the 2002 Act), which effectively ratified existing legal practice. It is the ground of necessity which underpins the Act and justifies the doctor's actions. A criminal offence is not committed when a doctor performs euthanasia or assists a patient's suicide provided she complies with the due care criteria laid down in the 2002 Act and reports her actions. ${ }^{11}$ The criteria are as follows: the patient's request was 'voluntary and carefully considered'; she was informed of her situation and prospects by the doctor; her suffering was 'unbearable' and there was 'no prospect of improvement' in her condition (the due care criteria have been interpreted as requiring a medical condition which may be physical or psychological in nature); both doctor and patient were convinced that the suffering could not be alleviated through any other reasonable means; the doctor acted with 'due care and attention'; s/he consulted an independent physician who has given a written opinion as to the criteria being satisfied. ${ }^{12}$ The doctor must notify the municipal pathologist as required by the Law on Burial and Cremation. ${ }^{13}$ Since November 1998, Regional Review Committees (RRCs) review reported cases of euthanasia and have provided further elucidation of the due care criteria that physicians must comply with under Dutch law. If the Committee decides that the physician involved has not complied with the law, then only at this stage do the prosecution authorities becomes involved. ${ }^{14}$

\section{Case Studies}

\subsection{The Brongersma Case}

In 1998 - several years before the Law of 2002 - Dr Philip Sutorius assisted in the suicide of an 86-year-old man, Brongersma, on the grounds that he was suffering existentially as a consequence of a number of the side-effects of old age, ${ }^{15}$ which had rendered him feeling increasingly undignified and socially isolated. Sutorius had two independent consultants examine and talk to Brongersma, both of whom confirmed the view that in the absence of depression, the ex-senator was experiencing his life as unbearable due to his physical deterioration. Following Brongersma's death, Sutorius reported what had happened and the prosecutorial authorities decided to prosecute.

\footnotetext{
11) As stated under Parts 2 of Articles 293 and 294.

12) See further See J. Griffiths, H. Weyers and M. Adams, Euthanasia and Law in Europe (Oxford: Hart Publishing, 2008), p. 84.

13) Ibid., pp. 126-127.

14) Ibid., pp. 85-90.

15) Such as balance problems and incontinence.
} 
At first instance ${ }^{16}$ the District Court in Haarlem accepted the proposition that the deceased's suffering could not have been alleviated by other means, and so acquitted Sutorius on the grounds that that the defence of necessity allowed by the courts before the 2002 Act could be invoked for suffering of this nature. The prosecution appealed on the basis that the decision would invite an expectation of an unqualified right to patient self-determination, whilst also expressing their doubt as to the 'unbearable' nature of Brongersma's suffering. After considering whether it should be part of a doctor's professional duty to relieve such nonmedical existential suffering, the Dutch Court of Appeals in Amsterdam concluded that although doctors should be concerned about such suffering, and should seek to relieve it, this should not extend to providing PAD. Thus, Sutorius was found guilty although no punishment was imposed. He appealed his conviction and in December 2002 the Supreme Court upheld the decision, ${ }^{17}$ reiterating that 'a doctor who assists in suicide in a case in which the patient's suffering is not predominantly due to a "medically classified disease or disorder", but stems from the fact that life has become meaningless for him, acts outside the scope of his professional competence. ${ }^{18}$ This decision played a prominent role in the parliamentary debates leading to the 2002 Act; the responsible Ministers emphasized that non-medical suffering did not meet the requirements under the proposed law.

\subsection{The Heringa Case}

The fact that Moek did not get help from a physician and that I a layman had to help her is really very sad... I don't want to be a martyr, but if I am going to be convicted, let it be. ${ }^{19}$

Maria Heringa, 'Moek' (Mum), was a 99 year old woman living in a nursing home who was tired of old age and concerned about her increasing loss of control over her life. She was assisted in her suicide by her stepson, Albert Heringa, who provided her with the necessary medication. Moek was a very independent person who could no longer pursue her favourite hobby of reading, found no more pleasure in life and, in Heringa's words, felt that 'she had lost the direction of the play'. ${ }^{20}$ She was a member of the NVVE and had discussed her wish to have an assisted death with her stepson. A consultation with a doctor had taken place to ascertain whether she could receive lawful assistance under the medical model of

16) District Court Haarlem, 30 October 2001, no 15/035127-99; Tidjdschrift voor Gezondheidsrecht 2001/21.

17) Nederlandse Jurisprudentie 2003, no 167.

18) Griffiths et al., supra, n. 12, p. 37.

19) Heringa, quoted in F. Verbakel, "It was her own intense wish", Relevant 36(1) (2010). English summary retrieved 3 October 2010 at: www.nvve.nl/nvve-english/pagina.asp?pagkey=141931\&metkey=449. 20) "De laatste wens van Moek" (Mum's Last Wish); at: www.netwerk.tv/artikelen/de-laatste-wil-vanmoek-hele-documentaire. 
PAD. The doctor considered that she did not meet the due care criteria and she did not express her wishes with clarity. According to Heringa, Moek felt let down by the medical profession. Heringa saw that she was becoming desperate when she showed him pills that she had gathered in order to take her own life, but he realised that taking these drugs would not cause her to die. Whilst travelling abroad, he had obtained anti-malaria medication and he gave Moek these drugs (along with sleeping pills and anti-vomiting pills) so that she could take her own life. He consulted a criminal lawyer and made a video-recording of what occurred as evidence that she herself had made the final decision and taken the medication. He and his daughters stayed with Moek after she had taken the drugs and fallen asleep but they then left the home, as they did not want to arouse the suspicion of the staff who would wonder why they were staying longer than they normally would. ${ }^{21}$ Heringa was informed of Moek's death by a member of the nursing home staff early the following morning. A doctor recorded her death as a natural one. The video recording was broadcast on a Dutch television network in February 2010, ${ }^{22}$ as part of the NVVE's 'Completed Life' campaign. ${ }^{23}$ Heringa was questioned by the police and the Public Prosecutor in the city of Zutphen was contacted. ${ }^{24} \mathrm{He}$ is currently awaiting trial.

\subsection{The Schellekens Case}

In May 2009, the District Court in Almelo found Gerard Schellekens, the president of a Dutch right-to-die organisation, guilty of the offence of assisted suicide. ${ }^{25}$ He had provided the children of an eighty year-old woman suffering from Parkinson's disease with Pentobarbital, which she had then taken herself, after they had asked for his help. ${ }^{26}$ The Court judged Schellekens not to be a physician assistor and emphasised that the Dutch legislation evidenced the legislature's intention that assisted suicide should only be lawful where there would be medical supervision of the process and procedure, and where a doctor's decision would be scrutinised afterwards. In this particular case, the doctor treating the woman had refused to assist her suicide because he did not consider her suffering to be

\footnotetext{
21) See further, ibid.

22) Ibid.

23) Supra, n. 5.

24) See the Dutch Public Prosecution Service (Openbaar Ministerie) report, Verdachte gehoord over hulp bij zelfdoding, 24 February 2010. Retrieved 3 October 2010 at: www.om.nl/organisatie/item_144364/ item_147888/nieuwsberichten/@152979/verdachte_gehoord/.

25) LJN: BI5890, Rechtbank Almelo, 08/750709-07. Retrieved 3 October 2010, at: zoeken.rechtspraak. $\mathrm{nl} /$ resultpage.aspx?snelzoeken=true\&searchtype $=1$ jn \&ljn $=B I 5890 \& u \_l j n=B I 5890$.

26) Mag Ik Dood? 2009 (May I Die?). "HUMAN zendt 'Profiel: Gerard Schellekens' uit". Mag Ik Dood? 6 May 2009. Retrieved 3 October 2010 at: weblogs.hollanddoc.nl/magikdood/2009/05/06/human-zendtprofiel-gerard-schellekens-uit/.
} 
unbearable and hopeless. ${ }^{27}$ According to the Court, a non-medical professional's act of assisted death could only be lawfully excused in truly exceptional, catastrophic circumstances where there were no doctors available, such as that of war. Schellekens was sentenced to ten months imprisonment and is currently appealing against this sentence. ${ }^{28}$ This judgment clearly demonstrates that the exception to the offences of assisted suicide and euthanasia under the penal code only applies to physicians. Significantly, however, it was stated in the judgment that the current law does not go far enough in the view of many Dutch citizens, who might approve of what Schellekens did.

\title{
4. Is the Lawful Medical Model of Assisted Death Too Restrictive?
}

\begin{abstract}
We should actually all die before our 70th or 80th, exceptionally 90th birthday, but due to medical knowledge and technology we are kept alive increasingly longer. The ageing process meanwhile causes the same havoc as it has always done, but this just does not lead us to die. We still become deaf and blind, lose our balance and suffer from incontinence... Unless you die before all this or become mentally oblivious, this means that there will be an inevitable moment in which life becomes solitary, poor, nasty, brutish and too long ${ }^{29}$
\end{abstract}

\subsection{Should the Existing Model Recognise Existential Suffering?}

Existential suffering 'is a widely used but ill-defined concept' ${ }^{30}$ Notwithstanding this, terms applied to such suffering in the context of the Dutch debate reflect some commonality of understanding as to what it means to suffer existentially: the individual feels 'tired' or 'weary of life', or 'through with life'. The NVVE presents a list of factors that commonly feature in its notion of 'completed life' which includes bodily decline, a declining social network, dependency on care, loss of future and purpose and absence of prospects. Loneliness, in particular, is emphasised. ${ }^{31}$ Existential suffering tends to give rise to a request for an assisted death when the individual is in the latter, final years of life since it is during these

27) T. Sheldon, "Only doctors can carry out euthanasia in the Netherlands, ruling confirms" (2009) 338 BMJ 338 (2009) b2319.

28) 8 months of his sentence are provisional. Mag Ik Dood? 2009. "Hoger beroep Gerard Schelleken". Mag Ik Dood? 21 June 2009. Retrieved 3 October 2010, at: http://weblogs.hollanddoc.nl/magikdood/ 2009/06/21/hoger-beroep-gerard-schellekens/. The appeal was be heard by the Court of Appeal in Arnhem on 13 January 2011, but has been postponed indefinitely. See De Verdieping. "Het recht om zelf te beschikken" ("The right to decide themselves"). De Verdieping. 3 September 2010. Retrieved 3 October 2010, at: http://www.trouw.nl/achtergrond/deverdieping/article3191261.ece/Het_recht_om_zelf_te_ beschikken.html.

29) H. Wijsbek, "Lijden aan het leven, verlangen naar de dood" ("Existential suffering, desiring death"), Filosofie \& Praktijk Jaargang 27(1) (2006), 31-38.

30) P. Strang, S. Strang, R. Hultborn and S. Arnér, "Existential Pain - An Entity, a Provocation, or a Challenge?", Journal of Pain and Symptom Management 27(3) (2004), 241-250, 241. We note that Strang et al. refer to existential 'pain' rather than 'suffering' (the latter being what the Dutch law requires).

31) NVVE, supra, n. 5, 12 and 24. 
years that the characteristics of such suffering noted above are most regularly present. It is the values of autonomy and compassion that underpin the case for recognising existential suffering as a legitimate ground for providing assisted death. To allow assisted dying for those whose suffering stems from a medical condition but not for those whose suffering stems from social factors is, as McLean notes, surely inconsistent from an autonomy-based position. ${ }^{32}$ It is also inconsistent from an approach based on compassion since it involves recognition of suffering as 'legitimate' in some cases, but not in others.

Reflecting on the Moek case, such cases of LAD could be avoided if existential suffering were recognized as falling within the due care criteria as unbearable suffering with no prospect of improvement. According to research findings published in 2005, approximately 400 individuals a year in the Netherlands request PAD because they are 'weary of life' and their desire for PAD can be persistent. ${ }^{33}$ Yet it would seem that the majority of Dutch doctors would not be prepared to adopt an interpretation of unbearable suffering that would encompass being tired of life. ${ }^{34}$ This may be due to a general reluctance within the medical profession to recognise such suffering as medical, and/or the rigidity of the courts' and RRCs' interpretation of the due care criteria.

A strict legal interpretation of the due care criteria excluding existential suffering can be found in the Brongersma case. But it is significant that the Court of Appeals in Amsterdam did consider that doctors should be concerned about existential suffering, thereby indicating that existential suffering can be perceived to lie within the medical realm. Following the District Court in Haarlem's decision in the Brongersma case, a committee presided over by J Dijkhuis, an Emeritus Professor in clinical psychology and psychotherapy, was established by the Royal Dutch Medical Association (KNMG) in 2001 to consider norms surrounding assisted dying requests in cases of existential suffering. The Committee's report was published in 2004. It recommends that the medical profession's expertise should be considered to extend to existential suffering rather than limited to cases where individuals' suffering stems from a medical condition, since such suffering can be unbearable and hopeless; the source of the suffering is not the deciding factor. ${ }^{35}$ The KNMG's response to the Committee's report has been cautious. It accepts the Committee's view that existential suffering is a complex issue, yet is

\footnotetext{
32) McLean, supra, n. 2, 181.

33) M.L. Rurup, M.T. Muller, B.D. Onwuteaka-Philipsen, A. van der Heide, G. van der Wal and P.J. van der Maas, "Requests for euthanasia or physician-assisted suicide from older people who do not have a severe disease: an interview study", Psychological Medicine 35 (2005), 665-671, 669 and 670.

34) According to a study conducted by Rurup et al. involving 412 physicians, requests for PAD based on being 'weary of life' were only granted in approximately one case. See M.L. Rurup, Setting the Stage for Death: New themes in the euthanasia debate (Amsterdam: Amsterdam VU, 2005) p. 29. And see infra, n. 39.

35) KNMG, Op zoek naar normen voor het handelen van artsen bij vragen om hulp bij levensbeëindiging in geval van lijden aan het leven: verslag van de werkzaamheden van een commissie onder voorzitterschap van prof. J Dijkhaus (Amsterdam: KNMG, 2004).
} 
seeking further clarification from within the medical profession as to whether such suffering should be perceived to fall within or outside the medical domain. ${ }^{36}$ The KNMG's Director of Policy has stated that it is a lack of government funding that has prevented research being carried out on this matter. ${ }^{37}$ One explanation for the muted response to the Committee's Report is that it is thought to be too politically sensitive. ${ }^{38} \mathrm{~A}$ further explanation is that the Committee's findings are not popular with the majority of doctors. According to Pans, $74 \%$ of medical professionals do not support extending the medical model of assisted dying to existential suffering. ${ }^{39}$ A KNMG medical ethicist has stated that the KNMG is opposed to the idea that existential suffering should be a recognised ground for a medically assisted death since 'it would go too far by making physicians responsible for resolving all suffering. ${ }^{40}$ It seems that for Dutch medical professionals, the matter of whether the alleviation of existential suffering is a medical matter is a grey area on which differing opinions exist. ${ }^{41}$ This should come as no surprise, given that evidence exists to suggest that doctors are reluctant to provide an assisted death even when it is clearly lawful for them to do so, ${ }^{42}$ and research findings have also revealed that they often find unbearable suffering the hardest of the due care criteria to reach a judgement upon. ${ }^{43}$

So should existential suffering be accepted as a legitimate ground for requesting an assisted death under the existing medical model? ${ }^{44}$ Whether or not existential suffering can be perceived to fall within the medical realm depends upon how narrowly or broadly we construe the concept of health. A narrower understanding

\footnotetext{
36) "Lijden aan het leven' ("Suffering from life"), Nieuws, 14 January 2005.

37) See "Als de dood aarzelt" ("When death hesitates"), Vrij Nederland. Retrieved 3 October 2010, at: http://www.vn.nl/Archief/Justitie/Artikel-Justitie/Als-de-dood-aarzelt.htm.

38) B. Keizer, "Zonder handschoenen: Uit vrije wil" ("Without gloves: free willed"), Medische Contact, 4 March 2010.

39) E. Pans, "Rapport 'Lijden aan het leven' een stap te ver?" ("Report 'existential suffering': a step too far?"), NJb, 8 April 2005. The findings of research conducted by Rietjens et al. reveal that only $18 \%$ of GPs and $27 \%$ of consultants involved in the study considered being tired of life to amount to unbearable suffering. J.A.C. Rietjens, D.G. van Tol, M. Schermer and A. van der Heide, "Judgement of suffering in the case of a euthanasia request in the Netherlands", JME 35 (2009), 502-507, 504.

40) Supra, n. 37.

41) Supra, n. 38.

42) Griffiths et al., supra, n. 12, pp. 46, 188 and 515-516; M.C. Janson-van der Weide, B.D. OnwuteakaPhilipsen and G. van der Wal, "Granted, Undecided, Withdrawn, and Refused Requests for Euthanasia and Physician-Assisted Suicide", Arch Intern Med 165 (2005), 1698-1704; J-J. Georges, A.M. The, B.D. Onwuteaka-Philipsen and G. van der Wal, "Dealing with requests for euthanasia: a qualitative study investigating the experience of general practitioners", JME 34 (2008), 150-155.

${ }^{43)}$ H.R.W. Pasman, M.L. Rurup, D.L. Willems and B.D. Onwuteaka-Philpsen, "Concept of unbearable suffering in context of ungranted requests for euthanasia: qualitative interviews with patients and physicians", BMJ 339 (2009), 4362; H.M. Buiting, J.K.M. Gevers, J.A.C. Rietjens, B.D. OnwuteakaPhilipsen, P.J. van der Maas, A. van der Heide and J.J.M. van Delden, "Dutch criteria of due care for physician-assisted dying in medical practice: a physician perspective", JME 35 (2008), 502-507.

44) For consideration of the blurred boundaries between existential suffering and suffering caused by medical conditions, see Ost, supra, n. 2; R. Huxtable and M. Möller, "Setting a Principled Boundary? Euthanasia as a Response to 'Life Fatigue', Bioethics 21(3) (2007), 117, 121.
} 
of health would be confined to 'qualities of vigour, suppleness, and fluidity' that illness affects and which it is 'the task of medicine to restore'. ${ }^{45}$ Such a concept of health that draws a connection between health and illness would be much more likely to exclude existential suffering from the medical realm. However, as Jacobs has recognised, the World Health Organisation's broad definition of health as 'a state of complete physical, mental and social well-being and not merely the absence of disease or infirmity', might be seen as inviting physicians to engage in alleviating existential suffering where such suffering is affecting an individual's well-being. ${ }^{46}$ To illustrate how such an understanding might be facilitated, we can consider the analogy Wijsbek has drawn between existential suffering and pregnancy. Pregnancy is not an illness, but it affects health and is perceived to be a medical matter because it causes pain and suffering and this suffering can be alleviated by medical professionals who have the necessary knowledge and skills to do so. Thus, pregnancy is considered to be a medical matter because medical knowledge and skills are necessary to alleviate the pain it causes. Similarly, Wijsbek argues that if existential suffering can only be alleviated by doctors, then it can be perceived to fall within the medical domain. ${ }^{47}$ But if the claim is that suffering can only be seen to be a medical matter when medical professionals alone can ease it, this may be problematic in the context of existential suffering as a ground for requesting an assisted death. In cases where an individual desires an assisted death because he is tired of life, surely his suffering can only be relieved through death: this is the basis of his request. Whilst medical professionals may well be the group in Dutch society with the greatest knowledge and skills regarding alleviating pain through death, knowledge as to the most appropriate drug to use to bring about a comfortable death can be possessed by non-medics. Indeed, this information is possessed by suicide counsellors from right-to-die organisations such as De Einder, ${ }^{48}$ and is communicated to individuals who wish to commit suicide.

Given this difficulty, an alternative way of conceiving existential suffering as a medical matter might be to broaden the concept of illness so that it applies to social issues pertaining to individual existence and experience such as loneliness and weariness, thereby encompassing the 'condition' of being tired of life. Notably, Cassell defines suffering as a state of severe distress associated with challenges that threaten the personhood or intactness of the person, rather than a more

\footnotetext{
45) M. Foucault, The Birth of the Clinic (London: Routledge, 2003), p. 40.

46) J.M. Jacobs, Doctors and Rules (London: Routledge, 1988), p. 56.

47) Supra, n. 29.

48) "I talk with people about their possible suicide... once they have made their decision, we discuss the means they have: whether they have the right medication, if they know how to use the medication." De Einder counsellor Ton Vink, quoted in "Assisted Suicide: The legal tightrope", Radio Netherlands Worldwide, 25 July 2005. Retrieved 3 October 2010 at: www.rnw.nl/english/article/assisted-suicide-legal tight-rope.
} 
medical notion of suffering which is primarily attributable to physical pain. ${ }^{49}$ Thus, the concept of illness or disorder could be applied to a patient's situation when s/he is experiencing a combination of old age, functional limitations and psychosocial factors that cause existential suffering. ${ }^{50}$ In other words, the amalgamation of factors that cause existential suffering comes to be recognised as an illness; the individual's life has become an illness. It is therefore noteworthy that the Dijkhuis Committee presents existential suffering as 'suffering from life' rather than being 'finished with living', in order to convey the real impact of the suffering. For the Committee, suffering from life amounts to suffering from the prospect of continuing to have to live when the individual experiences no or only limited quality of life and this results in a persisting wish to die. ${ }^{51}$ Such a presentation effectively conveys the notion that it is the continuation of life which is causing the individual to suffer. Interestingly, it has been argued that the terminology used to describe existential suffering towards the end of life charges the debate with emotional rather than evidence based arguments. ${ }^{52}$ Yet it is surely difficult to offer terminology to describe such suffering that has no emotional connotations given the nature of existential suffering, especially elements such as loneliness, loss of future and purpose. Whilst it is possible to adopt more scientific, medicalised terminology, ${ }^{53}$ this may fail to convey that the suffering is primarily caused by social factors, 'such as the loss of a partner, increasing isolation due to death of people around them, and physical ailments [which] can make everyday life... a negative experience' ${ }^{54}$

Herein lays the potential problem with extending the medical model of assisted dying to encompass existential suffering: medicalisation. Once the inherently medicalised concept of illness is applied to existential suffering, such suffering may come to be 'defined and treated' as a medical problem. ${ }^{55}$ This may gradually lead to the true (social) nature of the phenomenon becoming concealed. But, if it is accepted that existential suffering is just as legitimate a ground for requesting

49) E.J. Cassell, "The Nature of Suffering and the Goals of Medicine", N England J Medicine 306 (1982), 639-645.

50) A classification considered by Pans, supra, n. 39.

51) KNMG, supra, n. 35, 14. The Committee goes on to state that in this situation, the lack of or poor quality of life is not caused by a somatic or psychological condition.

52) C. Leget, G. Olthuis, A. Baart, F. Vosman, "Roep om publieke regeling komt te vroeg: Nog niet Klaar met 'voltooid leven"' ("Call for public regulation comes too soon. Not yet ready with 'accomplished life'”), Medische Contact, 4 March 2010.

53) For instance, in a study involving palliative physicians and pain specialists, 'palliative care physicians focused on issue of meaning and death anxiety, which can amplify the suffering from pain and which definitely reduce quality of life regardless of whether pain is present. The pain specialists emphasized the pain of living, with never-ending suffering, particularly in relation to chronic pain.' Strang et al., supra, n. 30, 246.

54) Rurup et al., supra, n. 33, 670.

55) P. Conrad, The Medicalization of Society: On the Transformation of Human Conditions (New York: JHU Press, 2007), p. 4. 
an assisted death as suffering caused by a medical condition, it may be worth running the risk of medicalisation to better ensure a change in the law. What we are getting at here is that legal reform is more likely to occur if existential suffering can be perceived to fall within the ambit of the accepted medical model, since this would be less of a drastic change than reforming the law by introducing a new model of assisted dying that recognises existential suffering as a form of 'social' suffering outside the medical domain. Moreover, introducing such a model would require acceptance of a whole new rationale, as the existing medical model is based on the accepted rationale of the doctor facing a conflict of duties between her duty to preserve life and her duty to alleviate suffering - necessity justifies her actions. ${ }^{56}$ If existential suffering is seen as falling outside the medical realm, there can surely be no duty upon the doctor to relieve it. The new rationale for legalising assisted dying requested on the grounds of unbearable existential suffering would thus have to be autonomy. Whilst some have claimed that autonomy is the hidden principle underlying the 2002 Act, ${ }^{57}$ it has never been the formally recognised and accepted rationale behind the lawful assisted dying model. ${ }^{58}$

At the start of this section, we also highlighted compassion as an underpinning principle justifying the recognition of existential suffering as a legitimate ground for requesting an assisted death. It may be that as the position which is founded upon a strictly medical assessment of suffering becomes increasingly stressed, the issue of compassion further evolves into a key determining element in Dutch policy, just as it has in other jurisdictions. ${ }^{59}$ The Dutch legal position is founded upon principles which already incorporate some consideration of compassion. The original defence of necessity (noodtoestand), which excused a physician who felt compelled to comply with a patient request for an assisted death, rests on the premise that no other course of action would satisfactorily relieve suffering. Consequently, a doctor who provided an assisted death in the face of such terrible pressure is viewed to have acted professionally rather than criminally. It seems apparent that the assessment of whether the doctor's actions fell within professional parameters invites an appraisal of whether the doctor acted compassionately or with some other motivation. Only when the hopelessness and unbearable suffering of the patient renders it compassionate for a doctor to comply with the patient's request, is the doctor viewed as having acted properly.

A less strictly medical assessment of the basis of suffering might open the door to greater emphasis being placed upon compassion, so that rather than adhering to the Supreme Court's rationale in Brongersma, Dutch authorities might move

\footnotetext{
56) See early case law such as Alkmaar, Nederlandse Jurisprudentie 1985, No.106, 451; Griffiths et al., supra, n. 12, p. 33.

57) As noted (but not supported) by Griffiths et al., ibid.

58) Ibid., p. 49.

59) For example, in both Germany and Columbia, killing out of compassion provides a partial defence to murder.
} 
away from strictly assessing the nature of suffering to instead assessing whether a doctor, such as Sutorius, had acted compassionately under the circumstances. Interestingly, this approach has recently been adopted (or at least elucidated) by the Director of Public Prosecutions in England and Wales ${ }^{60}$ in relation to the offence of Assisting or Encouraging Suicide, although not necessarily in relation to doctors, who appear to be at greater risk of prosecution than lay people. ${ }^{61}$

A policy which focuses more on the compassionate motivations of potential suspects, rather than the health of those seeking an assisted death, will nevertheless continue to appraise the reasons for the death wish, including whether suffering was present. This is because the notion of compassion is inextricably linked to suffering. It is arguably inconceivable that assistance could be regarded as compassionate unless a person was truly suffering without prospect. Accordingly, an approach which appraises compassion would therefore avoid a slide into unfettered autonomy, because a person would continue to require a compelling (and rational) reason for seeking death if $s /$ he hoped to engage another's assistance.

If existential suffering is recognised as falling within the medical domain by adopting one of the approaches suggested earlier in this section, there would be important implications for the legal medicalised model of assisted dying. Concern has been raised about the difficulties physicians would face should the medical model of assisted death be extended to existential suffering. Wijsbek has questioned how physicians will be able to judge when such suffering becomes unbearable in a way that would enable like cases to be treated alike. In his view, this judgement would inevitably be normative and would depend on the life of the particular individual patient. ${ }^{62}$ Given these concerns, although we have already noted that introducing a new lawful model of assisted dying would require a more drastic change in the law, it is worth considering the form that such a model might take.

\subsection{A New Model for those 'Tired of Life??}

A new model encompassing existential suffering, underpinned by the principles of autonomy and compassion, could be based on that put forward by the citizens' action group behind the Citizen's Initiative, Out of Free Will. The group has proposed that assisted death should be permissible in the case of individuals over the age of 70 who consider their lives to be accomplished because, one of the

\footnotetext{
60) The Director of Public Prosecutions has promulgated a code which indicates that a person assisting or encouraging the suicide of a competent adult is unlikely to face prosecution if he or she was motivated 'wholly by compassion'. See CPS, Policy for Prosecutors in Respect of Cases of Encouraging or Assisting Suicide (Crown: London, 2010). Retrieved 3 October 2010, at: www.cps.gov.uk/publications/prosecution/ assisted_suicide_policy.html.

61) A. Mullock, "Overlooking the Criminally Compassionate: What are the Implications of Prosecutorial Policy on Assisting or Encouraging Suicide?", Med L Rev 18(4) (2010), 442-470.

62) Supra, n. 29. See also Pans, supra, n. 39.
} 
group's leaders argues, when a person feels that he has no more life left in him, he should be able to say so, and act on it. ${ }^{63}$ In terms of the proposed process, nonphysicians (specially trained nurses, psychologists or spiritual professionals) would be the assistors and the individual would take the drugs provided by the assistor, supervised by the assistor. It is therefore only assisted suicide in this situation and not euthanasia that the group is demanding should be permitted. A health care professional's confirmation of the validity of the individual's wish to die would also be required. Notably, physician involvement is discernibly absent throughout the proposed process - it is the trained specialists who would also assess the individual's competence and that the request is well considered and not the product of depression. After the assisted suicide has taken place, the procedure would mimic that currently required to be completed under the medical model of assisted death - the assistor would write a report for the municipal coroner and the case would then go before the relevant RRC for assessment.

The group's proposal would avoid the medicalisation concerns raised above that might materialise if existential suffering is 'shoe horned' into the medical model, but it raises numerous questions. Perhaps the most obvious of these is whether the proposed minimum age limit of 70 is arbitrary. The group's rationale for imposing a high minimum age limit is that assisting young people to die 'cannot be justified', since older people 'understand more' and have 'more perspective' ${ }^{64}$ However one of the group's founders, Eugene Sutorius has commented that 'whether [the age limit] should be 65 or 90 is a good question' ${ }^{65}$ Whilst the age range the group has in mind is obviously one that spans the latter years of life, there is, we would argue, a real difference between the ages of 65 and 90. A 65 year old man could be described as a 'young pensioner', having only just become eligible for the AOW Dutch state pension scheme and it is more likely that some of his friends and family members will still be alive and that the 'burdens' of old age will be less than in the case of a 90 year old. With this in mind, although a 65 year old might consider he has no life left in him, would the rationale of having a 'completed life' really convince in his case? Would it accord with compassion to assist him in his death? This also raises the issue of the group's framing of the rationale for permitting assisted death in the circumstances they have in mind. By presenting the situation as one of an accomplished or completed life rather than 'suffering from life', the element of suffering seems to be absent, or at least, less conspicuous than the element of respecting autonomy. As we have suggested above, the need to establish suffering (albeit not necessarily from medical origin) should remain as crucial as respecting autonomy to avoid a trip down the slippery slope. It is true that in the examples the group present on their web site, all the

63) See "Citizens group argues "right to die", NRC Handelsblad, 8 February 2010.
64) Ibid.
65) Ibid. 
individuals are suffering from some kind of medical condition, disability, or the ravages of old age. ${ }^{66}$ However, the conditions that the group suggest must be met in order for the individual's death to be lawfully assisted prioritise autonomy: the request must be voluntary, informed and consistent and the individual must be mentally competent. The group emphasises that 'the voluntary and well considered decision of an elderly person who wants to die is obviously the central condition'. The only condition that appears to involve an assessment of suffering is that it must be possible to empathise with the request. ${ }^{67}$ Although this suggests that there must be some form of suffering to enable an understanding as to why the request is being made, the group provides no real explanation of what exactly this condition requires. As such, it remains ambiguous and appears almost as an afterthought to the conditions that relate to autonomy. We submit that any model which recognises existential suffering as a legitimate ground for requesting an assisted death should be presented in a way that clearly gives equal weight to suffering (thus compassion) and autonomy, in order to avoid becoming a model that offers assisted death 'on demand'. ${ }^{68}$

Whether existential suffering should be a legitimate ground for requesting an assisted death is not an issue that is going to go away. Significantly, according to research published in $2003,45 \%$ of the population considered that elderly people who were tired of life should be provided with drugs to enable them to take their life. ${ }^{69}$ In March 2008, a poll conducted by the Dutch research bureau Intomart GfK was published, in which $74 \%$ of the 1,000 people surveyed supported the controlled distribution of 'suicide' pills to those who considered their lives to be completed. ${ }^{70}$ The matter can now only be more prominent in Dutch social and political debates in the wake of the NVVE's Completed Life campaign and the Citizen's Initiative we have discussed. Notably, it took only four days for the necessary forty thousand signatures to be collected in support of the Initiative's demand for legal reform. The Dijkhuis Committee predicted that it was likely that requests for an assisted death because of existential suffering will increase in future, ${ }^{71}$ and this is supported by the NVVE's observation that the over- 65 population in the Netherlands 'is more autonomous, focusing on independent choices

66) Uit Vrij Wil. 2010. "Om wie gaat het". Retrieved 3 October 2010, at: www.uitvrijewil.nu/index .php?id=1002.

67) 'Empathetic' being the translation of the word the group uses: 'invoelbaar'. See Uit Vrij Wil. 2010. "Schets van stervenshulp aan ouderen”. Retrieved 3 October 2010 at: www.uitvrijewil.nu/index .php?id=1006.

68) See the discussion in Section 6.

69) G. van der Wal, Medische besluitvorming aan het einde van het leven: de praktijk en de toetsingsprocedure euthanasia en het Verslag van de begeleidingscommissie van het evaluatieonderzoek naar de medische besluitvorming aan het einde van het leven (Utrecht: de Tijdstroom, 2003), p. 104. Cited in Griffiths et al., supra, n. 12 , p. 38.

70) "FAQ - Euthanasia in the Netherlands", Radio Netherlands Worldwide, 29 September 2009. Retrieved 3 October 2010, at: www.rnw.nl/english/article/faq-\%E2\%80\%93-euthanasia-netherlands.

71) Supra, n. 35. 
and is socially critical' ${ }^{72}$ Notwithstanding this, it is worth noting that the fate of any future proposed model which encompasses existential suffering may, in large part, be decided by whether the medical profession's response to it is favourable or unfavourable. ${ }^{73}$ There is no greater evidence of this than the history of the Dutch law surrounding euthanasia. ${ }^{74}$ The general reluctance within the medical profession to accept existential suffering as a legitimate ground for a request for an assisted death does not, therefore, bode well for the success of any model which is supportive of allowing an assisted death on the basis of 'suffering from life'. It also appears that the Dutch government would be reluctant to liberalise the law surrounding PAD. ${ }^{75}$ Yet unless legal reform does occur, some of the individuals who desire control over their deaths but are denied a lawful medically assisted death will look elsewhere for assistance.

\section{Criminals or Victims of Circumstance? Relatives and Other Lay Assistors}

It is somewhat inevitable that the matter of LAD is interconnected with existential suffering, since if doctors refuse to comply with a patient's request for PAD because of a concern that they will fail to act in accordance with the criteria of the lawful medical model of assisted dying, the patient has to turn elsewhere for help. ${ }^{76}$ But the fact remains that there is no exception to the law prohibiting assisted suicide and euthanasia in the case of any lay assistor. Thus the strict (appropriate?) legal response to a law assistor should be prosecution, followed by trial and, if the individual is found guilty, a punishment proportional to the gravity of the crime committed. What, then, is the legal response to LAD in practice?

To begin with cases involving relative assistors, prosecutions are few and far between and, prior to the Moek case, the prosecutions that did occur took place

\footnotetext{
72) NVVE, supra, n. 5, 10. See also NVVE, Perspectives on Dying with Dignity (Amsterdam: NVVE, 2008), p. 13. Retrieved 3 October 2010, at: http://www.nvve.nl/assets/nvve-english/publications/ PerspectivesOnDying.pdf.

73) J. Coggon, "Assisted-Dying and the Context of Debate: 'Medical Law' Versus 'End-of-Life Law' ", Med L Rev 18(4) (2010), 541-563, n. 45; F. Pakes, "Under Siege: The Global Fate of Euthanasia and AssistedSuicide Legislation", European Journal of Crime, Criminal Law and Criminal Justice 13(2) (2005), 119135, 134-135.

74) See Pakes, ibid., 131; and J. Griffiths, A. Bood and H. Weyers, Euthanasia and Law in the Netherlands (Amsterdam: Amsterdam University Press, 1998), p. 304.

75) S. Gevers, "Evaluation of the Dutch Legislation on Euthanasia and Assisted Suicide", European Journal of Health Law 14(4) (2007), 369-379, 370.

76) There is the possibility of stopping eating and drinking whilst receiving palliative care to hasten death. This, however, can take some time, requires assistance from others and some knowledge of the palliative care required in order for a 'good death' to occur. See B. Chabot, A Hastened Death by Self-denial of Food and Drink (Amsterdam, 2008), 21; S. Ost, "Physician Assisted Dying Outlaws: Self-Appointed Death in the Netherlands", forthcoming, Clinical Ethics 16(1) (2011).
} 
some time ago. ${ }^{77}$ Interestingly, some of the relatives who were prosecuted in the earlier cases received not insubstantial prison sentences, one of which was for one and a half years. ${ }^{78}$ Now, the Public Prosecution Service (hereafter PPS) sees hardly any such cases and according to ad hoc, anecdotal evidence, in cases that do come to the attention of the authorities, the PPS may decide not to prosecute because of the consideration that the assistor has been through enough. ${ }^{79}$ It would seem that the legal response to $\mathrm{RAD}$ reflects the notion that a relative assistor has been through enough of an ordeal, ${ }^{80}$ having seen his loved one suffer and then having had to assist them in their suicide when there is no alternative lawful means of assisted dying available to them. There is certainly room for the argument that the relative assistor can be seen as a victim of circumstance because the loving relationship they have with the person who wishes to die pressurises them to help them fulfil their loved one's wish to die, coupled with their own desire not to see their relative suffer. ${ }^{81}$ While in the Heringa case, this has not meant that the assistor has escaped prosecution, we submit that if Heringa is found guilty by the court, the imposition of a severe punishment would be surprising for the reasons we outline below.

Unsurprisingly, the broadcast of the 'De laatste wens van Moek' (Moek's Last Wish) documentary generated much discussion and controversy. Although some of those who have voiced their opinions are strongly against what Heringa did, there is notable public support for his actions. ${ }^{82}$ The compassionate public response may encompass medical professionals since the fact that the PPS sees almost no reports of non-medical cases of assisted dying suggests either that cases

\footnotetext{
77) See Griffiths et al., supra, n. 12, p. 112. It seems that the most recent of these occurred in the late 1980s (involving a husband and a friend who assisted) and the most well known was the Postma case, Nederlandse Jurisprudentie 1973, no.183, 558 (although as the assistor was also a doctor, it was not strictly viewed as a RAD case). See Griffiths et al., supra, n. 74, pp. 53-54 and 60.

78) Ibid., p. 53. In the case referred to above involving the husband and friend, a conditional sentence of six months was imposed and the court considered the friend to be more culpable than the husband. Personal communication with Heleen Weyers, 4 November 2010.

79) Personal communication with John Griffiths in April 2010, who has spoken to prosecutors from the PPS on this matter.

80) Ibid.

81) This is the approach often taken in mercy killings cases tried under English law, when the defendants have pled diminished responsibility to reduce a charge of murder to voluntary manslaughter. See S. Ost, 'Euthanasia and the Defence of Necessity: advocating a more appropriate legal response' in: C.A. Erin and S. Ost (eds) The Criminal Justice System and Health Care (Oxford: Oxford University Press, 2007), 99, pp. 105-109.

82) See the varied comments posted about the documentary at Netwerk TV. 2010. "Documentaire Moek zorgt voor veel commotie" ("Mum documentary causes much commotion"). Netwerk TV. February 2010. Retrieved 3 October 2010, at: www.netwerk.tv/uitzending/2010-02-10/documentaire-moekzorgt-voor-veel-commotie; the comments posted at Vrijspreker.nl. 2010. "Ingezonden: Burgerinitiatief Uit Vrije Wil” (“Citizens Initiative 'Out Of Free Will' submitted”). Vrijspreker.nl. 13 February 2010. Retrieved 3 October 2010, at: http://www.vrijspreker.nl/wp/2010/02/burgerinitiatief-uit-vrije-wil/; and note again the afore-mentioned support for the Citizen's Initiative and the text accompanying nn. 69 and 70, supra.
} 
of RAD rarely occur, or that they are being reported as natural deaths by doctors and families. Research conducted by Chabot indicates that cases of RAD are indeed occurring, alongside other cases in which individuals obtain the medication that they need to end their lives through the assistance of others. In a fifth of the 1,600 cases he examined, doctors were aware of the situation and knowingly supplied the medication. Moreover, some doctors reported the deaths as natural when they were aware that an instance of RAD had occurred. Although in other cases individuals obtained the pills they needed from their doctor or chemist through false pretences, Chabot's research suggests that at least some physicians are sympathetic to assisted suicides that fall outside of the lawful medical model. ${ }^{83}$

If the contemporary legal and social response to relative assistors is sympathetic in the way we have suggested above, might knowledge of the likely (sympathetic) response to their actions enable relative assistors to make a powerful statement when they transgress the criminal law, a statement that the current legal position is inappropriate? Applying Foucault's analytics of power, ${ }^{84}$ the Moek case reveals an interesting relationship of power and confrontation between law and the 'criminal' and may provide an example of a strategic reversibility of power relations. ${ }^{85}$ As Foucault famously commented, where there is power, there is resistance. ${ }^{86}$ Although the PPS has the power to prosecute, to make Heringa the subject of the law's power and face the strict criminal law repercussions of his actions, he has devised a confrontation strategy. ${ }^{87}$ Heringa has arguably manoeuvred himself into a more powerful position by recording the offence he committed, getting the NVVE on board and taking steps to have his mother's assisted suicide broadcast on Dutch television, in the knowledge that there would be public support for his actions as a relative assistor. Heringa's confrontation strategy forced the Public Prosecutor to prosecute him to confirm the law's power, but in so doing, the inadequacies of this power may be revealed. While the PPS had to take action given the evidence, when the case reaches the court, the presiding judge will also be aware that if Heringa is found guilty, the imposition of anything but a sympathetic penalty is likely to face public criticism. We therefore submit that there is a strong possibility that if he is convicted, a minimal sentence will be imposed. A violator of the criminal law will thereby effectively go unpunished or receive a minimal sanction. If this is the end result, Heringa, the 'crimi-

\footnotetext{
83) Griffiths et al., supra, n. 12, pp. 183-184, citing Chabot's research: B. Chabot, Auto-euthanasie: verborgen stervenswegen in gesprek met naasten (Amsterdam: Uitgeverij Bert Bakker, 2007).

${ }_{84)}$ M. Foucault, History of Sexuality, vol 1, (New York: Pantheon, 1978), p. 82.

85) M. Foucault, "Afterword: The Subject and Power", in: H.L. Dreyfus, and P. Rabinow, Michel Foucault: Beyond Structuralism and Hermeneutics (Brighton, Sussex: The Harvester Press, 1982), pp. 208-226, 224-226.

86) Supra, n. 84, 95. See also D. Lacombe, "Reforming Foucault: A Critique of the Social Control Thesis", British Journal of Sociology 47(2) (1996), 332-352, 342.

87) Supra, n. 85, at pp. 224-245.
} 
nal' here, can be perceived to be an individual who has utilised his circumstances to attract public attention and gain a more sympathetic legal response, rather than a victim of circumstance. Although in legal discourses, his identity is as the 'criminal', he is actively challenging this identity through his communication with the Dutch public and confrontation strategy with the law. He is engaging in a process of subjectification, ${ }^{88}$ constituting himself (and potentially other relative assistors) through his resistance to the label of 'criminal'. ${ }^{89}$ Moreover, his actions might further the case for legal reform by encouraging collective deliberation regarding the limited medicalised exception to the criminal law surrounding assisted death.

However, another recent case of RAD suggests that the more sympathetic approach which appears to be taken towards relatives by the prosecutorial authorities and the courts is not adopted where the lay assistor is a friend rather than a relative. A month after a psychiatric patient's first unsuccessful attempt to commit suicide (at which his friend, the suspect in the case, was present), he asked the suspect to buy him heroin and methadone. The suspect obtained the drugs from a drug user on the street. In the knowledge that his friend intended to take his own life by taking a lethal overdose of these drugs, the suspect gave him the drugs and syringes and left his house. ${ }^{90}$ The decision of the District Court of 's-Hertogenbosch was that the suspect was not guilty of murder under Article 289, but was guilty of the offence of assisted suicide. The Court ruled that a 15 months custodial sentence was appropriate in this case. ${ }^{91}$ The reasoning given was that in taking the decision to assist, the suspect was making an assessment as to the deceased's quality of life that he was not qualified to make and had acted outside the strict controls of the medical model. Moreover, he had involved a third party, the drug user, in an interaction that could nearly be classified as criminal behaviour. The Court wished to discourage others from acting as the suspect had done.

In contrast, imposing a custodial sentence in a RAD case might not be considered an effective method of deterring others from acting in the same way, since in such a situation, the strong emotional bond could override any reasons not to assist. Did the friend assistor also face a harsher legal response because a friend is not judged to be facing the same pressure as a relative? Or is this case distinctive

\footnotetext{
${ }^{88)}$ Foucault's concept of the process through which individuals become subjects. Foucault, supra, n. 85, p. 218. See also M. Foucault, "Two Lectures on Power", in: M. Foucault (C. Gordon (ed.)), Power) Knowledge: Selected Writings, Interviews \& Other Writings 1972-1977 (New York: Pantheon, 1980), pp. 78-107, 97-98. We are following Heller's interpretation of Foucault's concept of subjectification here as a process in which the subject can actively (rather than always passively) engage in his own constitution: K.J. Heller, "Power, Subjectification and Resistance in Foucault", SubStance 25(1) (1996), 78-110, 92.

89) Lacombe, supra, n. 86, 350 (n. 4).

90) LJN: AW2803, District Court 's-Hertogenbosch, 01/839087-05.

91) The defendant served 10 months of his sentence -5 were conditional.
} 
because the drug that the friend obtained and the manner in which he obtained it meant that a stricter legal response was more likely? Answers to these questions are not provided in the judgment, but this case demonstrates that a strict rather than a sympathetic legal response is more likely in such cases of LAD.

This strict approach is also apparent in cases where members of right-to-die organisations are the assistors, as evidenced by the decision and sentence in the Schellekens case. ${ }^{92}$ It is significant that although the woman's children gave their mother the drugs that Schellekens provided, they were not prosecuted. Notably, the position taken by the prosecutorial authorities in cases where members of right-to-die organisations are the assistors does not appear to have altered over the years as it has done regarding $\mathrm{RAD} ;{ }^{93}$ prosecutions are more likely in cases where the assistor is a member of a right-to-die organisation rather than a relative. ${ }^{94}$ Anecdotal evidence suggests that this might be because the former are more likely to know about possible alternative lawful options..$^{95}$ When a member of a rightto-die organisation does not go as far as Schellekens did, either merely providing advice and information about how to commit suicide and/or being present when the individual commits suicide, whether this amounts to the offence of assisting suicide under Article 294 depends on the level of intervention. Where the individual does not actually provide instructions or direct the suicide, it seems that the assistance stops short of constituting criminal assistance. ${ }^{96}$ If, however, the individual provides the means to commit suicide, or is present at the suicide and takes an active role, this can constitute criminal assistance. ${ }^{97}$

As we noted at the start of this section, there is a connection between the lack of recognition of existential suffering as a ground for requesting an assisted suicide under the lawful model of PAD and the occurrence of LAD. It seems a logical postulation that if such suffering were to be seen as a legitimate ground for providing an assisted death when it is unbearable and there is no prospect of improvement, then fewer individuals would have to turn to their relatives and other lay people for assistance in dying. But would revising the lawful medical model in this manner constitute a trip down the slippery slope?

\footnotetext{
92) See also the cases discussed in Griffiths et al., supra, n. 12, p. 47.

93) As evidenced by the prosecution of right-to-die activists in the Wertheim case, Nederlandse Jurisprudentie 1982, no. 63 (although the punishment imposed was sympathetic in light of Ms. Wertheim's age (76) - see Griffiths et al., supra, n. 12, pp. 58-59) and the cases cited in n. 97, infra.

94) Ibid., p. 112.

95) Supra, n. 79.

96) See the Cornelisse case, Tijdschrift voor Gezondheidsrecht 2004: 178-179.

97) See, for example, the Mulder case, Dutch Jurisprudence 1996, no 322; the Muns case, Tijdschrift voor Gezondheidsrecht 2004: 173-178; and the Hilarius case, LNJ: AY7270, Court of Appeals Amsterdam, 23-006489-05. See further P. Admiraal, B. Chabot, R.D. Ogden, A. Rietveld and J. Glerum, Guide to a Humane Self-Chosen Death (Delft: Wozz Foundation, 2006), pp. 96-99.
} 


\section{The Slippery Slope}

Undoubtedly one of the most common arguments put forward against the legalisation of assisted dying is that pertaining to the slippery slope. Because slippage can only really be assessed once legalisation has occurred, the Dutch experience clearly has the potential to either refute or confirm slippery slope allegations. ${ }^{98}$ Consequently, the recent developments in the Netherlands which form the focus of this article, provide the opportunity to consider whether some of the fears of those who prophesized that no good would come of legalising assisted death have been confirmed. As we might expect, the Dutch are anxious to refute the claim that their highly regulated model of PAD has fallen victim to slippage, however, the evidence presented in this article suggests that, for some, the existing limits of assisted dying are too restrictive. The consequent pressure which is being exerted in an attempt to stretch current boundaries may thus be seen as representing slippage down a dangerous slope towards unfettered autonomy. The tension between i) the decision in Brongersma and the subsequent Dijkhuis Committee report, and ii) the strict legal categorisation of the relative assistor as criminal and the sympathetic legal response, demonstrates how Dutch society may be torn between extending the autonomous rights of individuals who are genuinely suffering on the one hand, whilst at the same time maintaining the appropriate level of medical engagement within a highly-medicalised model of assisted-dying. This section of the article seeks to explore the implications of these developments in light of the ongoing assessment of whether the Dutch experience evidences a trip down the slippery slope.

\subsection{Principles of the Slippery Slope}

Before focusing on the specific elements of the slippery slope debate which are most relevant when considering extending PAD to those suffering existentially, it is useful to first outline the various theories of the slippery slope. Broadly speaking, slippery slope arguments rest upon the assumption that people are unable to abide by distinctions between morally acceptable behaviour and related, but morally unacceptable, behaviour. Thus, slippery slope arguments have a particular resonance in the debate on assisted dying, with the key proposition being that if

\footnotetext{
98) Although it should be noted that the information emerging from the Netherlands from the five-yearly national research, which has been subject to scrutiny in relation to assessing slippage, has been interpreted very differently by commentators. Contrast Griffiths et al., supra, n. 12, with J. Keown, Euthanasia, Ethics and Public Policy: An Argument against Legalisation (Cambridge: Cambridge University Press, 2002). See also, J.A.C. Rietjens, P.J. van der Maas, B.D. Onwuteaka-Phillipsen, J.J.M. van Delden, A. van der Heide, "Two Decades of Research on Euthanasia from the Netherlands. What Have We Learnt and What Questions Remain?” Bioethical Enquiry 6 (2009), 271-283; M.P. Battin, A. van der Heide, L. Ganzini, G. van der Wal and B.D. Onwuteaka-Phillipsen, "Legal Physician-assisted Dying in Oregon and the Netherlands: Evidence Concerning the Impact on Patients in 'Vulnerable Groups'”, JME 33 (2007), 591-7.
} 
voluntary euthanasia is legalised it will become impossible to make a distinction between voluntary euthanasia and non voluntary or even involuntary euthanasia.

Slippery slope arguments may be categorised as either empirical ${ }^{99}$ or logical. The empirical strand of the argument contends that legalisation will defy effective regulation, and so morally acceptable ${ }^{100}$ and permissible PAD will inevitably open the door to morally unacceptable and impermissible PAD. For example, doctors might fail to adequately ensure that requests for PAD are genuine and well-considered, or might overlook alternative ways to relieve suffering. Moreover, the argument runs, any number of mistakes, or simply a lack of care, regarding diagnosis or prognosis will result in PAD being performed inappropriately. In addition to this inadvertent slippage, a further slide may occur because attitudes (of either doctors or the public) will change because of relaxation of the law. Previous abhorrence of killing will melt away and doctors or society may come to regard $\mathrm{PAD}$ as a solution to social problems in an increasingly aged society, and so the only way we can avoid such slippage from the acceptable to the unacceptable is to continue to prohibit assisted dying.

The logical aspect of the slippery slope argument proposes that the ethical justifications for allowing PAD; namely beneficence and autonomy, will naturally invite at least one of two morally problematic conclusions. The first conclusion, resting on the presumption that PAD may only be permitted when it is in the interests of the patient in order to end suffering and is therefore beneficent, is that voluntary euthanasia is only acceptable if non-voluntary euthanasia is acceptable. Keown illustrates this contention with imaginary terminally ill twins, $\mathrm{X}$ and $\mathrm{Y}$, under the care of Dr A, who, having agreed that the competent twin's request for euthanasia should be complied with, feels duty-bound to terminate the life of the incompetent twin who is suffering in silence. ${ }^{101}$ The second conclusion, resting on the justification of patient autonomy, is that if we allow those suffering unbearably from a terminal illness to have an assisted death based on their autonomous request, what is to prevent us from respecting the requests of healthy individuals who have other - equally autonomous - reasons for preferring death?

As one might expect, the various strands of the slippery slope debate have been the subject of some scrutiny. Stephen Smith, for example, has considered both the empirical and logical arguments, providing a comprehensive and compelling response to Keown's treatise. ${ }^{102}$ Also, Lillehammer has addressed aspects of the debate, with a persuasive rebuttal of Keown's central argument over the logical

\footnotetext{
99) Also sometimes referred to as the 'practical' slippery slope. See Keown, ibid., p. 72.

100) Assuming of course that other objections to PAD, such as the sanctity of life argument, are put to one side.

101) See Keown, supra, n. 98, 78.

102) See S. Smith, "Evidence for the practical slippery slope in the debate on physician-assisted suicide and euthanasia", Med L Rev 13(1) (2005), 17-44. Also, S. Smith, "Fallacies of the Logical slippery slope in the debate on physician-assisted suicide and euthanasia", Med L Rev 13(2) (2005), 224-243.
} 
slippery slope. ${ }^{103}$ More generally, others have considered the merits of such arguments, ${ }^{104}$ providing a useful basis upon which to further consider the slippery slope in relation to the extension of PAD for those suffering existentially.

\subsection{Physician-assisted Dying for the Terminally Old?}

In consideration of slippery slope concerns pertaining to the developments discussed herein, it seems that elements of both the empirical and logical strands of the argument are relevant to the pressure to extend the grounds for PAD to encompass existential suffering. Empirically speaking, where once it appeared that there was a consensus that it was justifiable to provide PAD only to those suffering unbearably from some medically diagnosed disease or condition, recent developments invite the presumption that attitudes have shifted. Of course, this is not an entirely novel development; it is apparent that there may inevitably be some tension between subjective and objective perceptions of suffering, and whether the patient's or doctor's assessment should be most crucial. ${ }^{105}$

However, although there may be little political will to extend the suffering criteria, and despite evidence that doctors are generally reluctant to provide PAD, ${ }^{106}$ it seems that the prominence of cases such as Brongersma and 'Moek', together with the Citizens' Initiative and the conclusions of the Dijkhuis Committee, provide some evidence that attitudes have indeed changed. This is not uncharacteristic of the Dutch assisted dying debate. According to Pool, the 'Dutch euthanasia debate... is an ongoing and complex socio-cultural, medical, legal, and ethical process which has been characterised by increasing tolerance of physician assisted death, creeping jurisprudence culminating in the legalisation of euthanasia... and a gradually shifting limit to what is considered ethically acceptable. ${ }^{107}$ Volokh refers to such shifts as 'attitude-altering slippery slopes', ${ }^{108}$ and questions whether such changes in attitude are necessarily bad, suggesting that some changes in attitude resulting from legal change might be described as 'good learning' rather than 'bad desensitization'. ${ }^{109}$ Whilst this is undoubtedly true in general — for

103) H. Lillehammer, "Voluntary euthanasia and the logical slippery slope argument", CLJ 61(3) (2002) 545-550.

104) For example see, D. Enoch, "Once You Start Using Slippery Slope Arguments, You're on a Very Slippery Slope", OJLS 21(4) (2001), 629-647; E. Volokh, "The Mechanisms of the Slippery Slope”, Harvard Law Review 116 (2002-2003), 1026-1137.

105) Rietjens et al., supra, n. 39. Notably, the 2009 annual report of the RRCs emphasises that it is the patient's assessment as to whether the suffering is unbearable that should be determinative on this matter: Regional Euthanasia Review Committees: 2009 Annual Report (The Hague, 2010), p. 22. Retrieved 27 February 2011, at: http://www.euthanasiecommissie.nl/doc/pdf/jaarverslag\%2ORTE\%202009\%20 -Engelse\%20vertaling-23705.pdf.

106) Supra, n. 42.

107) R. Pool, “'You're not going to dehydrate mom, are you?': Euthanasia, versterving, and good death in the Netherlands", Social Sciences and Medicine 58 (2004), 955-966, 955.

108) Supra, n. 104, 1104.

109) Ibid. 
example, the decriminalisation of homosexuality in the late 1960s clearly encouraged less homophobic attitudes within society - highly contentious issues such as assisted dying are understandably more troubling. Moreover, it may be inevitable that those opposed to the Dutch law on PAD will see the ongoing debate on existential suffering as evidence of exactly the type of slippage envisaged. But is this fair? If the subject under consideration was a slide from voluntary euthanasia to non-voluntary or even involuntary euthanasia it would be easy to reach a consensus that a terrible slide had occurred, but with an altogether different kind of shift; namely, with Dutch opinions divided on the question of whether PAD should be available to those suffering existentially, how should these developments be viewed?

At the heart of this debate lies the issue of autonomy. Because the current dilemma focuses on whether to extend PAD to those suffering existentially, it is clear that Keown's argument in relation to the logical slippery slope has not (yet?) transpired; both the suffering (beneficence) and the request (autonomy) remain crucial. However, this debate does demonstrate that the founding principle of the Dutch law - that PAD is justified on the basis of necessity only when requested by a patient who is suffering unbearably from a medical condition (hence the defence of necessity is grounded in beneficence) ${ }^{110}$ — is under some stress. Autonomy remains crucial; clearly dispelling Keown's assertions regarding non-voluntary euthanasia, but with the nature of the suffering necessary in order to invoke physician-participation under dispute, the contours of the founding principle of necessity appear less stable. PAD opponents would argue that the first slide down the slope occurred with the Chabot case, ${ }^{111}$ which confirmed that patients suffering psychologically might lawfully receive help in dying. Whilst the Supreme Court's ruling in the Brongersma case prevented further movement by maintaining the existing parameters of physician involvement, Dr Sutorius's actions clearly illustrated a problem which seems to be growing.

On the issue of autonomy, perhaps a useful analogy may be drawn between assisted dying and abortion. The Abortion Act $1967^{112}$ was enacted in order to protect women from the perils of backstreet abortions, and so its key ethical justification was non-malfeasance with respect to avoiding dangerous, unhygienic practices and the enhancement of public health. Although female autonomy was clearly promoted by the Abortion Act, this was essentially a side-effect and not the primary purpose of the legislation. Nevertheless, autonomy and a woman's right to choose has become the key ethical justification in the ongoing abortion debate, and so parallels might be drawn between the post legalisation primacy of

\footnotetext{
110) See P. Lewis, "The Dutch Experience of Euthanasia", Journal of Law and Society 25(4) (1998) 636649, 637; Griffiths et al., supra, n. 74, p. 172.

111) Nederlandse Jurisprudentie 1994 No. 656, Supreme Court. See Griffiths et al., ibid., p. 153.

112) Essentially, the Abortion Act provides a limited criminal defence to Sections 58 and 59 of the Offences Against the Person Act 1861, both of which concern the unlawful procurement of a miscarriage.
} 
autonomy relating to abortion and the growing primacy of autonomy in the assisted dying debate. ${ }^{113}$

The legitimacy of both abortion under the Abortion Act and PAD (in the Netherlands) depends upon the cooperation of two physicians who must ensure that the legal requirements are met on the grounds of there being sufficient healthrelated evidence. On the issue of abortion, the 'health' grounds outlined by the Abortion Act under section 1(1) provide that it shall not be an offence for a physician to terminate a pregnancy on various grounds. The first of these is that the pregnancy has not exceeded its twenty fourth week and that the continuation of the pregnancy would involve risk, greater than if the pregnancy were terminated, of injury to the physical and mental health of the pregnant woman or any existing children of her family. The 'physical and mental health' element of this provision has allowed a degree of flexibility which in turn has promoted the idea that there is a 'right' to choose not to continue an unwanted pregnancy. Again, the question of what constitutes 'health' is a key determining factor. The Royal College of Obstetricians and Gynaecologists suggest that its reference to health is generally assumed to adopt the wider understanding provided by the World Health Organisation's definition. ${ }^{114}$ Thus, with respect to a woman's physical health, a termination is generally less risky than pregnancy and so will usually pose less risk to a woman's physical health. Similarly, the mental well-being of a woman who does not want to be pregnant will almost always be enhanced by a termination.

Unsurprisingly, this has been the subject of some debate. For example, Keown has opined, 'Even ardent pro-choicers would have to concede that, although the Abortion Act 1967 permits abortion for medical not social reasons, abortion for social reasons has become the norm, or at least commonplace. '115 Consequently, those opposed to abortion have seized upon the escalation in so called 'social' abortion as evidence to confirm the power of slippery slope arguments in relation to not only abortion but also assisted dying. ${ }^{116}$ However, whether it is morally acceptable to afford greater importance to autonomy than to a strictly medical assessment of health or suffering is, of course, highly subjective, being entirely dependent upon not only one's view of the morality of abortion and PAD generally, but also upon one's opinion regarding the importance of autonomy in connection to these issues.

Ultimately, the moral character of the developments we have discussed and evidence of pressure upon the existing model of PAD in the Netherlands will

113) We note that there are some important differences in the respective ethical dilemmas posed by the two issues. For example, the abortion debate is subject to pressure from those concerned with fetal rights. See J. Finnis, "The Rights and Wrongs of Abortion: A Reply to Judith Thomson", Philosophy and Public Affairs 2 (1973), 117-145.

114) See supra, text accompanying n. 46. See also E. Jackson, Medical Law: Text, Cases and Material (Oxford: Oxford University Press, 2010), p. 677.

115) See Keown, supra, n. 98, 71.

116) Ibid., 74 . 
inevitably invite conflicting views. Naturally, those opposed to the very concept of assisted dying will seize upon these developments as further proof that slippage is occurring. Arguably, however, whilst the Dutch model of PAD may be under some stress, the stress is very much focused on the nature of suffering, inviting questions about the possible re-drawing of clinical concepts of suffering. There will always be those who call for greater emphasis upon self-determination in this context, but in reality the Dutch model of PAD is unlikely to be re-defined because of autonomy. Rather, if there is to be any re-drawing of boundaries, it will be with reference to the concept of suffering.

\section{Conclusions}

Pakes has observed that:

policy-making in the Netherlands tends to be pragmatic; it tends to follow practices evolved in society. Legislation is often aimed at giving existing practices a legal footing, with the subsequent aim of gaining control over such practices by means of guidelines, licences and other forms of regulation. ${ }^{117}$

It is an accepted part of Dutch culture that assisting another individual to die because of unbearable suffering without prospect of improvement can be legitimate. Recent developments such as the Moek case and the Citizens Initiative suggest that political debate must take place on whether this exception to the criminality normally attached to causing or assisting another's death should be extended to a situation where the suffering is existential. If it is indeed the case that a significant amount of the Dutch population favours a change in the law, then surely this suggests that legal reform is required. For, as Dripps asks, 'Should any person be punished as a criminal for violating a norm that a substantial minority of the polity, after sustained debate, rejects?'118

Extending lawful assisted dying to cases where existential suffering is the rationale for wishing to die would result in a more socially designed model of assisted dying. It may be problematic to 'fit' existential suffering into the existing medical model and this could lead to medicalising the phenomenon of existential suffering. Furthermore, any proposal for law reform that would extend the existing medical model to encompass existential suffering is likely to encounter a major obstacle - opposition from the medical profession - that will need to be overcome. But notwithstanding this, it is our view that if legal reform does occur, it is

${ }^{117)}$ F. Pakes, "Tolerance and pragmatism in the Netherlands: euthanasia, coffeeshops and prostitution in the 'purple years' 1994-2002", International Journal of Police Science and Management 5(4) (2003), 217$228,226$.

118) D. Dripps, "The Liberal Critique of the Harm Principle", Criminal Justice Ethics 17(2) (1998), 3-18, 12 . 
more likely to be facilitated through extending the medical model in this way than through a system such as that proposed by the group behind the Citizen's Initiative. The proposal would involve too significant a move away from the accepted medical model to be the basis of legal reform at this time. And we have argued that the proposal prioritises the importance of autonomy over compassion and suffering and that this could lead to a slippery slope towards unfettered autonomy. It is crucial to ensure that if it does become accepted medical and legal practice to extend the due care 'suffering' criterion to existential suffering, this practice is transparent so that all concerned can witness the effects of this practice and if it is deemed to be an undesirable slide down the slippery slope, action can be taken. ${ }^{119}$

Another approach to legal reform would be for prosecutors to disproportionately enforce the criminal prohibition on assisted dying which does not comply with the lawful medical model, so that in cases like Moek which generate a sympathetic reaction, the decision is taken not to prosecute. Such an approach would require further consideration of whether the distinction drawn between relatives and other lay assistors is appropriate. But moving forward in this way would be problematic because it would take the pressure off the legislature to carefully consider the continued appropriateness of the criminal prohibition on assisted dying in cases where the suffering is non-medical in origin or the assistor is a relative compelled to act because of a close tie of love and affection. ${ }^{120}$ In the case of relative assistors, we are thus left with the question 'what purpose is served by a law which technically criminalises behaviour which it then effectively ignores or forgives? ${ }^{121}$

119) Griffiths et al., supra, n. 12, p. 518, n. 13.

120) Dripps, supra, n. 118, 14.

121) Mclean, supra, n. 2, 144. 